\title{
Looking at a 14th-Century Recipe against Skin Disease
}

\author{
Stella Fatović-Ferenčića ${ }^{a}$ Marija-Ana Dürrigl ${ }^{b}$ \\ aDepartment for the History of Medicine, Croatian Academy of Sciences and Arts, and \\ bOld Church Slavonic Institute, Zagreb, Croatia
}

In the vaults of the archive of the Croatian Academy of Sciences and Arts in Zagreb, a fairly large collection of Glagolitica is kept, i.e. manuscripts and early printed books in the Glagolitic alphabet. That alphabet was created by St. Cyrill of Thessaloniki in the 9th century and intended to be used by the newly Christianized Slavic peoples. The alphabet was soon replaced in the East by the Cyrillic script and in the West by the Latin script - only in parts of Croatia did the Glagolitic alphabet survive in liturgy, law and literature well into the 19th century. Several Glagolitic monuments with specific medical subjects have also been preserved.

We have singled out a clipped 14th-century recipe against skin disease, which poses a challenge for philological and medicohistorical analysis [1]. The recipe is short; it was not written by a member of the learned elite, but most likely by a practitioner who had not even been a trained physician, probably a monk or priest. However 'unimpressive' this source may be, it is an illustration of what kinds of medical texts came down to us from the Middle Ages, and what kind of 'medical practice' and 'therapeutic procedure' they reflect.

\section{The 14th-Century Recipe against Skin Disease}

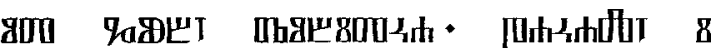

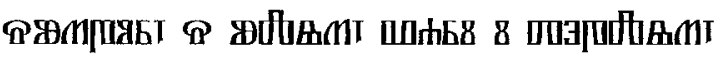

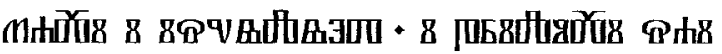

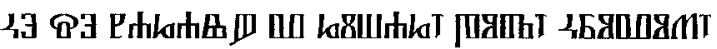

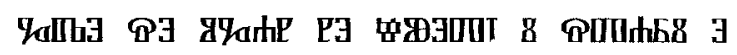

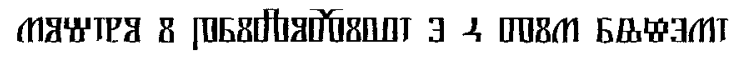

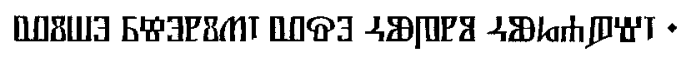

The recipe suggests that sulfur, bitumen and soot (i.e. soot found under the roofs of houses - coming from the fire on a hearth, the smoke finding its way out through a lantern on the roof of the house) should be mixed with warm oil and applied to the skin, which will then heal.

The prescription is rather rational in its approach. All prescribed elements are chemical substances known for their healing properties from ancient times. Sulfur is a yellow nonmetallic chemical element used for various purposes during centuries against skin diseases, such as ringworm, eczema and leprosy. The ancient Greeks and Romans prepared various ointments mixing sulfur with goose dripping, and they also used it as a cleanser. Dioscurides suggested it as a remedy against cough, as an inhala-

Dr. Marija-Ana Dürrigl

Old Church Slavonic Institute

Demetrova 11

CRO-10000 Zagreb (Croatia)
Fax + 41613061234 E-Mail karger@karger.ch www.karger.com (c) 2000 S. Karger AG, Basel

1018-8665/00/2013-0189\$17.50/0

Accessible online at: www. karger.com/journals/drm 
tion against asthma and for external use in healing skin conditions. During the medieval period, many alchemists used it as a remedy. Traces of all that experience can be found in the well-known Regula Salernitana which read: 'Contra fistulam auripigmentum, sulphur, miscere memento, his decet apponi calcem, comisce saponi' [2], which means: 'Against fistulas: remember to mix sulfur with arsenic trisulfide, to these you must add lime and mix it with soap'. Bitumen/resin was widely applied already in ancient Egypt, where it was used for mummification due to its preserving qualities, and it was applied also because of its anti-inflammatory action. All mentioned ingredients are known for having antiseptic properties and are still contained in a number of modern preparations (except goose dripping).

At the end of the recipe, the scribe states

meaning 'it (i.e. the skin) will heal'. This is indicative because it points to the belief in the cure of the complaint, in the effectiveness of the prescribed drug (based arguably on experience), but it may also clarify from the semantic point of view what kind of disorder it might have been, namely from Old Slavonic to modern standard Croatian iscijeliti the meanings are 'sanare, curare' in the narrower sense 'to regenerate', i.e. to make complete, whole again, which applies particularly to the skin [3].

\section{Semantic Analysis - Probable Diagnosis}

The presented recipe is a typical example of how difficult it is to identify conditions described in old, almost formulaic terms from a modern point of view. The recipe opens with a 'diagnosis' reading 'Ot gubb' which is terminologically not transparent. Dictionaries dealing with oldest Slavic sources have the following translations for guba: (1) sponge (spongia); (2) leprosy (lepra); (3) fungus on a tree. Some translations make it even more difficult to interpret, e.g. in one source the adjective gubav is translated as 'aussätzig, šugav' [4] which is misleading - German aussätzig means 'leprous', Croatian šugav means 'having/suffering from scabies'. The term 'gubs' in our recipe appears to refer to the disease now known as leprosy or a variety of conditions producing lesions on the skin. It is clear that our knowledge of historical epidemiology of diseases rests on paleopathological and other evidence far more than on (written) descriptions. However, if the range of the disease in medical texts is not a useful guide to historical epidemiology, it surely is a good source of information about the way in which illness was understood and recognized, and about the kind of problems which were considered worth treating [5]. The analyzed text sheds light on methods long past, looking at a recipe which may be 600 years old.

\section{Conclusion}

The presented recipe is a rarity for its linguistic and paleographic value, for the fact that its content is exclusively rational, based on empirical knowledge, for its precise use of mineral stuff (while the majority of preserved Glagolitic recipes are based on herbal ingredients) and for preserving an instruction for healing throughout six centuries. On the other hand, by its technical processing of medicine based on folk manufacturing, it is part of the general atmosphere of the medieval European medical heritage.

\section{Acknowledgement}

The authors gratefully acknowledge the assistance of Professor Karl Holubar.

\section{References}

1 Recipe Collection, Manuscript, 14th Century. Zagreb, Croatian Academy of Sciences and Arts, shelfmark HAZU IV d 56.

2 Gherli F (ed): Regimen Sanitatis Salernitanum (La regola sanitaria Salernitana). Rome, Newton Compton, 1993, p 41.

3 Anić V: Rječnik hrvatskoga jezika. Zagreb, Novi Liber, 1991, p 209.
4 Skok P: Etimologijski rječnik hrvatskoga ili srpskoga jezika. Zagreb, JAZU, 1971, p 628.

5 Siraisi NG: Medieval and Early Renaissance Medicine: An Introduction to Knowledge and Practice. Chicago, Chicago University Press, 1990, p 130. 